\title{
Sumbangsih Cendikiawan dalam Penerjemahan Buku-Buku Ilmu Pengetahuan (Studi pada Masa Pemerintahan Dinasti Abbasiyah) Erna Kurniawati
}

Fakultas Dakwah dan Komunikasi UIN Sunan Kalijaga Yoyakarta, ernhadena@gmail.com

\begin{abstract}
Abbasid dynasty is one dynasty that has a high civilization in the field of knowledge, of course this is inseparable from the efforts made by the caliph Harun Ar-Rasyid and Al-Ma'mun to translate the works that civilizations want to watch in the field of science, with the help of translators who have capabilities in foreign mastery languages. About the purpose of this article is to map the names of figures who had a major contribution to the development of science during the Abbasid Dynasty. By using the theory made as a knife of analysis in this study, the reasons for policies are decisions taken by people who have a budget to set a matter in accordance with the desired goals. While for this researcher will use the method of library analysis from various sources related to the history of Islamic civilization, both from books, research journals and related literature, to then be mixed and analyzed, conclusions are also obtained. Thus the results of this study indicate that the movement of translators of knowledge books does have an interesting interest for translators who come from outside the city of Baghdad also outside of Islam, to come translating special books, in order with the rewards and awards given by the caliph out of proportion to their hard work.
\end{abstract}

\section{Keywords: science; translator movement; Abbasid dynasty}

Abstrak

Dinasti Abbasiyah merupakan salah satu dinasti yang memiliki peradaban tinggi pada bidang ilmu pengetahuan, tentunya hal ini tidak terlepas dari usaha yang dilakukan oleh khalifah Harun Ar-Rasyid dan Al-Ma'mun dalam melakukan gerakan penerjemah karya-karya asing yang terlebih dahulu mengalami peradaban di bidang ilmu pengetahuan, dengan melibatkan penerjemah yang memiliki kapabilitas dalam penguasaan bahasa asing. Adapun tujuan dalam artikel ini adalah untuk memetakan nama-nama tokoh yang telah memiliki sumbangsih besar terhadap perkembangan ilmu pengetahuan pada masa Dinasti Abbasiyah. Dengan menggunakan teori kebijakan yang dijadikan sebagai pisau analisis dalam penelitian ini, sebab kebijakan merupakan sebuah keputusan yang diambil oleh orang yang memiliki kekuasaan untuk menetapkan suatu hal demi tujuan yang diinginkan. Sedangkan untuk peneliti ini akan menggunakan metode analisis pustaka dari berbagai sumber-sumber terkait dengan sejarah peradaban Islam, baik itu dari buku, jurnal penelitian dan literature-literatur terkait, untuk kemudian diramu dan dianalisis, dipilah serta ditarik kesimpulan. Dengan demikian hasil dari penelitian ini menunjukkan bahwa gerakan penerjemah buku-buku ilmu pengetahuan memang memiliki ketertarikan sendiri bagi para penerjemah yang berasal dari luar Kota Bagdad maupun di luar agama Islam, untuk datang menerjemahkan buku-buku asing, tentunya dengan upah dan penghargaan yang diberikan oleh khalifah sebanding dengan kerja keras mereka.

\section{Kata Kunci: ilmu pengetahuan; gerakan penerjemah; Dinasti Abbasiyah}

\section{A. PENDAHULAN}

Fungsi ilmu pengetahuan bukan hanya semata-mata sebagai sebuah disiplin ilmu pengetahuan, yang tercatat dan tertulis dalam lembaran-lembaran kertas dan disusun menjadi sebuah buku, tapi bagaimana ilmu pengetahuan tersebut dapat difungsikan serta berguna dan bermanfaat untuk kepentingan masyarakat dan agama. Bentuk pengaplikasian dari keilmuan itulah yang perlu disebarkan dan dipraktikan dalam gerakan dakwah yang bisa dilakukan, dengan cara menggagas sebuah keilmuan demi kemaslahatan umat, menyebarkan dan mengkontruksi peradaban manusia kepada yang lebih baik. Mampu menerima dari segala perbedaan paradigma dan menjadikannya sebagai khazanah ilmu pengetahuan, tanpa melihat 
latar belakang perbedaan SARA, sehingga mampu menerima dan membangun sikap keterbukaan dalam disiplin keilmuan.

Hal inilah yang kemudian dibuktikan oleh kepemimpinan Harun Ar-Rasyid beserta puteranya Al-Ma'mun pada masa pemerintahan Dinasti Abbasiyah, yang telah mencetak sebuah keberhasilan atau capain kejayaan. Bisa dilihat pada abad ke-8 sampai pada abad ke$12 \mathrm{M}$, umat Islam berada pada puncak kejayaan dalam bidang intelektual, berkat gerakan penerjemah buku-buku ilmu pengetahuan yang berasal dari bahasa Yunani, India dan Persia yang diterjemahkan kedalam bahasan Arab. Puncak kejayaan ini tercatat dalam sejarah tepatnya pada masa pemerintahan Dinasti Abbasiyah di Kota Bagdad yang digawangi oleh khalifah Abbasiyah ke-lima dan ke-enam yaitu Harun Ar-Rasyid dan puteranya Al-Ma'mun, dari Kota ini lahirlah berbagai disiplin bidang keilmuan dan filosof-filosof muslim, sehingga dengan demikian Kota ini dijuluki sebagai Kota Gudangnya Intelektual, yang memancarkan kebudayaan dan peradaban Islam keseluruh dunia, yang hingga sampai saat ini keilmuankeilmuan yang dihasilkan masih dimanfaatkan dan dikembangkan lebih lanjut oleh para ilmuan-ilmuan Timur maupun Barat.

Prestise politik, supremasi ekonomi dan aktivitas intelektual merupakan tiga pokok penting keistimewaan Kota Bagdad. ${ }^{1}$ Ilmu pengetahuan serta sastra juga mengalami perkembangan yang sangat pesat. Sebab pada saat itu umat Islam mampu menggapai kejayaannya karena memberikan perhatian lebih yang tidak hanya pada ilmu-ilmu agama, tetapi juga ilmu-ilmu umum serta ilmu-ilmu murni. Pemerintahan yang dibangun oleh Harun Ar-Rasyid dan Al-Ma'mun ini mencapai puncak kejayaan dalam berbagai disiplin bidang keilmuan dengan berlandaskan pada kejujuran, keikhlasan, kebenaran, keadilan serta rasa cinta yang tinggi terhadap ilmu pengetahuan.

Sedangkan untuk jumlah khalifah yang mengkomandoi Dinasti Abbasiyah secara turun temurun kurang lebih ada sekitar 37 khalifah yang pernah berkuasa, di mana pada masa dinasti inilah Islam mencapai puncak kejayaan dalam bidang pengetahuan. Pemerintahan Dinasti ini merupakan Dinasti Islam yang terpanjang dalam masa pemerintahannya antara 750-1285 $\mathrm{M}$ atau sekitar 500 tahun, jika dibandingkan dengan pemerintahan dinasti-dinasti yang lain. Selain itu terdapat pula perbedaan menonjol antara Bani Abbas dan Bani Umayyah, yang mana Bani Abbas lebih menekankan pada pembinaan peradaban dan kebudayaan Islam sedangkan Bani Umayyah lebih kepada perluasan wilayah. Hal ini terbukti pada pemerintahan pertama Bani Abbas yang telah mencapai puncak keemasan, secara politis para Khalifah adalah tokoh-tokoh yang kuat, selain mampu menguasai dari segi politik tapi juga agama mampu dikuasai. Di sisi lain pencapaian tertinggi adalah pada tataran kemakmurkan masyarakatnya, serta keberhasilan yang dicapai dalam menyiapkan landasan bagi perkembangan filsafat dan ilmu pengetahuan dalam Islam. ${ }^{2}$

Popularitas yang paling menonjol dari sekian banyak khalifah yang mengkomandoi Dinasti Abbasiyah adalah pada masa pemerintahan Harun Ar-Rasyid dan puteranya yaitu AlMa'mun dengan melakukan gerakan penerjemah dalam beberapa bidang keilmuan. Hingga banyak melahirkan seorang ilmuan-ilmuan muslim di bidang filsafat maupun bidang ilmu pengetahuan lainnya. Berkat kerja keras yang telah dibangun oleh kedua khalifah ini, sampai saat ini ilmu pengetahuannya berkembang pesat bahkan memiliki pengaruh yang sangat besar bagi keberlangsungan hidup manusia sampai sekarang baik di Timur maupun Barat. Dengan demikian maka penulis akan lebih mengfokuskan pada ke dua khalifah ini yang telah membagun peradaban Islam dalam bidang ilmu pengetahuan melalui gerakan penerjemah yang dilakukan, sehingga mampu membuat Islam berada di atas langit dan dikenal oleh dunia sebagai Islam yang berperadaban tinggi.

\footnotetext{
${ }^{1}$ Badri Yatim, "Sejarah Peradaban Islam”, (Jakarta : Pt Rajagrafindo Persada, 2013), h. 279

${ }^{2}$ Ibid., h. 50-53
} 
Kedua pemerintahan khalifah Harun Ar-Rasyid dan Al-Ma'mun memiliki visi misi yang hampir sama yaitu sama-sama memiliki kecintaannya terhadap ilmu pengetahuan, sehingga mereka melakukan kebijakan-kebijakan pada masa pemerintahannya yang berfokus pada peradaban di bidang sosial, kesehatan, pendidikan, ilmu pengetahuan dan kebudayaan. Meskipun kepemimpinan mereka tidak disandingkan pada periode pemerintahan yang sama, namun usaha Al-Ma'mun adalah melanjutkan peradaban yang telah dibangun oleh khalifah Harun Ar-Rasyid. Sehingga tidak heran jika masa kejayaan memang sudah sepantasnya disandang oleh kedua khalifah ini.

Kemajuan dan perkembangan yang telah dicapai pada masa kepemimpinan kedua khalifah tersebut diantaranya pada bidang ilmu pengetahuan umum dan agama, untuk ilmu pengetahuan umum sepertihalnya filsafat, astronomi, matematika, kedokteran, geografi, sejarah, fisika, kimia, sastra, arsitektur, seni rupa dan pada bidang seni musik, kemudian pada bidang ilmu agama ada ilmu hadis, tafsir, kalam, fikih dan ilmu tasawuf, yang mana semua keberhasilan ini adalah berkat usaha yang dilakukan melalui gerakan penerjemahan bukubuku asing dalam bahasa Yunani dan India begitupun Persia yang diterjemahkan ke dalam bahasa Arab, sebab bangsa mereka yang telah mengalami perkembangan dan kemajuan terlebih dahulu di bidang ilmu pengetahuan. Gerakan penerjemahan ini dilakukan oleh kedua khalifah ini dengan mengerahkan orang-orang yang mampu dan mempunyai kapabilitas dalam memahami bahasa asing untuk kemudian diterjemahkan dan ditulis kembali dalam bentuk bahasa Arab dan penerjemahannya sebagian dilakukan oleh orang-orang yang memiliki background non Islam.

Dengan demikian, artikel ini akan menjadi pelengkap bagi artikel-artikel sebelumnya yang membahas terkait pemerintahan masa Dinasti Abbasiyah. Selain itu, dengan melakukan penjabaran secara gamblang mengenai nama-nama setiap tokoh yang ikut serta dalam melakukan usaha penerjemahan buku-buku ilmu pengetahuan ke dalam bahasa Arab, diharapkan nantinya mampu menambah khazanah baru terkait nama-nama tokoh yang telah memiliki jasa besar terhadap perkembangan ilmu pengetahuan hingga sampai saat ini. Sebab jika dilihat dari literature review yang ada, terkait pemerintahan Dinasti Abbasiyah memang sudah banyak yang melakukan penelitian dalam hal ini, diantaranya ada Yanto yang meneliti tentang sejarah perpustakaan Bait Al-Hikmah pada masa Keemasan Dinasti Abbasiyah, penelitian ini lebih menekankan pada bagaimana sejarah perpustakaan Bait Al-Hikmah itu berdiri sampai dengan keberfungsiannya dan efek atau dampak yang ditimbulkan dengan adanya perpustakaan tersebut. ${ }^{3}$ Selanjutnya penelitian yang dilakukan oleh Alimni yaitu terkait peradaban pendidikan gerakan intelektual masa Abbasiyah yang lebih mengfokuskan pada latar belakang dan sebab-sebab terjadinya kemajuan yang dicapai oleh Dinasti Abbasiyah baik melalui adanya asimilasi bangsa Arab dan bangsa lain yang telah mengalami perkembangan ilmu pengetahuan terlebih dahulu dengan melakukan penerjemahan terhadap karya-karya asing ke dalam bahasa Arab guna menciptakan tradisi keilmuan yang kondusif. ${ }^{4}$

Untuk penelitian selanjutnya yang dilakukan oleh Imam Nurhakim lebih kepada kebijakan-kebijakan yang sudah dilakukan khalifah Al-Ma'mun pada masa pemerintahannya guna untuk perkembangan ilmu pengetahuan, dimulai dari pengembangan pendidikan Islam dengan mendirikan lembaga-lembaga pendidikan yang dijadikan sebagai sarana belajar dan pengembangan ilmu pengetahuan, selain itu Baitul Hikmah juga didirikan sebagai pusat

${ }^{3}$ Yanto, "Sejarah Perpustakaan Bait Al-Hikmah Pada Masa Keemasan Dinasti Abbasiyah”, (Fakultas Adab Dan Humaniora, Universitas Islam Negeri Raden Fatah Palembang : Jurnal Tamaddun Vol. Xv, No. 1/Januari - Juni 2015), h. 256

4 Alimni, "Peradaban Pendidikan; Gerakan Intelektual Masa Abbasiyah", (Dosen Luar Biasa Pada Fakultas Tarbiyah Dan Tadris, Iain Bengkulu : Jurnal Al-Ta'lim, Vol. 13, No. 2, Juli 2014), h. 343 
penerjemah buku-buku dan sarana halaqah dan mengkaji Islam. ${ }^{5}$ Salmah Intan juga melakukan penelitian mengenai kontribusi Dinasti Abbasiyah bidang ilmu pengetahuan, yang lebih mengfokuskan pada kontribusinya terhadap kemajuan umat Islam dalam bidang ilmu agama, filsafat, pendidikan dan sains. ${ }^{6}$ Kemudian untuk penelitian selanjutnya yang dilakukan oleh Mochamad Muksin mengenai Islam dan perkembangan Sains dan Teknologi (studi perkembangan sains dan teknologi Dinasti Abbasiyah), menjelaskan bahwa masa kejayaan Dinasti Abbasiyah diwujudkan oleh 7 orang khalifah dengan puncak kejayaan yang berhasil tercatat sebagai dasar dan wujud eksistensi bagi perkembangan ilmu pengetahuan dan filsafat yang menjadi pendorong perkembangan sains dunia. ${ }^{7}$

Sedangkan tujuan dari artikel ini adalah memetakan nama-nama tokoh yang telah berjasa dalam usaha penerjemahan buku-buku ilmu pengetahuan dari bahasa asing ke dalam bahasa Arab. Untuk selanjutnya akan dilakukan analisis dengan menggunakan metode analisis pustaka, yaitu datanya didapatkan dari hasil bacaan buku-buku sejarah terkait, jurnal dan penelitian lain yang relevan. Kemudian dikumpulkan, disajikan dan ditarik kesimpulan, sedangkan untuk rumusan dari penlitian ini akan lebih menitik beratkan pada siapa-siapa saja tokoh yang terlibat dalam usaha penerjemahan ilmu pengetahun yang dilakukan pada masa Dinasti Abbasiyah sehingga mampu mencapai kejayaan dalam bidang ilmu pengetahuan?

\section{B. Gerakan Penerjemah Dinasti Abbasiyah Sebagai masa kejayaan}

Gerakan penerjemah pada bidang ilmu pengetahuan adalah usaha untuk meramu dan memahi yang kemudian diterjemahkan atau ditulis kembali sesuai dengan pemahaman yang ia miliki. Usaha inilah yang dirintis oleh khalifah dari dinasti Abbasiyah yaitu pada masa kepemimpinan Harun Ar-Rasyid bersama dengan puteranya Al-Ma'mun. Berkat pemikiran dan usaha nyata yang dilakukan pada masa itu, Islam mampu memiliki cahaya terang dan mampu menyinari dunia dengan berbagai bidang ilmu pengetahuan yang dilahirkan dan inilah awal dari capaian kejayaan Dinasti Abbasiyah.

Sebelum kepada pembahasan mengenai seperti apa gerakan penerjemah yang dilakukan dan siapa-siapa saja orang-orang yang berjasa dalam menerjemahkan buku-buku ilmu pengetahuan, alangkah baiknya yang perlu dipahami terlebih dahulu adalah mengenai sejarah awal berdirinya Dinasti Abbasiyah dan masa kepemimpinan pemerintahan Harun Ar-Rasyid dan Al-Ma'mun yang telah mencetak masa kejayaan.

\section{B.1 Sekilas mengenai Dinasti Abbasiyah}

Dinamakan Dinasti Abbasiyah karena para pendiri dan penguasa dari dinasti ini merupakan keturunan Al-Abbas yaitu paman Nabi Muhammad Saw. Dinasti ini didirikan oleh Abdullah Al-Saffah ibn Muhammad ibn Ali ibn Al-Abbas, yang berkuasa selama rentan waktu dari tahun $750 \mathrm{M}$ sampai dengan $754 \mathrm{M}$, setelah itu berganti kepemimpinan yang dipegang oleh Abu Ja'far Al-Manshur (754-775 M). Kemudian untuk kekuasaan dinasti ini berlangsung dalam kurun waktu relatif panjang yaitu dari tahun $132 \mathrm{H}(750 \mathrm{M})$ sampai dengan $656 \mathrm{H}(1258 \mathrm{M})$, dengan pola pemerintahan yang berbeda-beda sesuai dengan perubahan politik, sosial dan budaya. ${ }^{8}$

Pada mulanya, ibu Kota dinasti Abbasiyah adalah Al-Hasyimiyah yang berada di dekat Kufah, namun pada masa kepemimpinan Al-Manshur di pindahkan ke Kota Bagdad dekat ibu Kota bekas Persia. Jika dasar-dasar pemerintahan dinasti Abbasyiah dibangun oleh Abu al-

5 Imam Nurhakim, "Kebijakan Khalifah Al-Ma'mun Tentang Pendidikan Islam”, (IAINU Kebumen : Jurnal An-Nidzam Volume 04, No. 01, Januari-Juni 2017), h. 31

6 Salmah Intan, “Kontribusi Dinasti Abbasiyah Bidang Ilmu Pengetahuan”, (Universitas Islam Negeri Alauddin Makassar : Junal Rihlah Vol.6 No. 2/2018), h. 166

${ }^{7}$ Mochamad Muksin, "Islam Dan Perkembangan Sains Dan Teknologi, Studi Perkembangan Sains Dan Teknologi Dinasti Abbasyiah", (Fakultas Teknologi Informasi, Universitas Negeri Malang : Jurnal Vol 2 , Nomor 4, 2016), h. 18

${ }^{8}$ Badri Yatim, "Sejarah Peradaban Islam", h. 49-50 
Abbas dan Abu Ja'far Al-Munshur, maka lain halnya dengan puncak keemasan yang dibangun oleh 7 khalifah setelah masa kepemimpinan mereka, diantaranya Al-Mahdi (775785 M), Al-Hadi (775-786 M), Harun Ar-Rasyid (786-809 M), Al-Ma'mun (813-833 M), AlMu'tashim (833-842 M), Al-Wasiq (842-847 M) dan Al-Mutawakkil (847-861 M). ${ }^{9}$

Meskipun telah tercatat dalam sejarah bahwa puncak keemasan ada di tangan 7 khalifah tersebut, namun kemajuan peradaban di bidang ilmu pengetahuan yang berkembang pesat dan paling menonjol, dicetak pada masa kepemimpinan Harun Ar-Rasyid dan Al-Ma'mun.

\section{B.2 Masa Kepemimpinan Harun Ar-Rasyid}

Usia yang cukup muda sekitar 25 tahun, Harun Ar-Rasyid sudah dipercayakan untuk menjadi khalifah dinasti Abbasiyah ke-5 menggantikan Al-Hadi. Untuk masa jabatan pemerintahannya sendiri berkisar kurang lebih selama 23 tahun terhitung dari tahun 786-809 $\mathrm{M}$ dan pemerintahannya merupakan awal masa kejayaan bagi sejarah dunia Islam belahan Timur. ${ }^{10}$

Dengan banyaknya jumlah kekayaan yang dimiliki, untuk kemudian dimanfaatkan demi kepentingan serta keperluan sosial, seperti halnya membangun rumah sakit, mendirikan lembaga pendidikan dokter serta farmasi dan sekitar 800 orang dokter telah mampu dilahirkan pada masa kepemimpinannya. ${ }^{11}$ Meminjam kutipan dari encyclopedia American vol. XIII edisi tahun 1976 yang terdapat pada halaman 834, menulis tentang masa pemerintahan Harun Ar-Rasyid bahwa : "nama Harun Ar-Rasyid dalam masa sekian lamanya termashur sekali dan menjadi buah tutur, baik di Timur maupun di Barat, mungkin sebagian besarnya disebabkan dia merupakan tokoh legendaris di dalam sebagian kisah-kisah seribu satu malam. Khilafat mencapai puncak kemakmuran dan kebudayaan pada masanya". ${ }^{12}$

Selain itu, adanya usaha gerakan terjemah yang dilakukan pada masa kepemimpinannya dan melahirkan karya-karya dalam bidang astronomi dan mantiq. Adapun cabang-cabang ilmu pengetahuan seperti matematika, fisika, astronomi dan kemiliteran juga ikut berkembang pesat pada masa pemerintahannya. Kemudian di pemerintahannya juga banyak melahirkan para ilmuwan diantaranya, Qadri Abu Yusuf, keluarga Bermakid, Abu Atahiyah, Ishak al-Mausuli dan lain-lain. ${ }^{13}$ Kemajuan-kemajuan yang dicapai dalam beberapa bidang oleh Harun Ar-Rasyid tidak terlepas dari gaya kepemimpinan yang dimiliki yaitu adanya sikap keterbukaan. Terbukti dengan adanya data sejarah mengenai kepribadiannya yang terkenal murah hati, lebih mengedepankan akal dari pada emosi serta senantiasa bersikap sopan santun dan dermawan pada seluruh rakyatnya.

Sedangkan sebagai tempat pusat penerjemah dari karya-karya asing, Harun Ar-Rasyid membangun Bait al-hikmah yaitu sebuah perpustakaan yang diberi nama Khizanah alHikmah. ${ }^{14}$ Pada periode ini, kekuasaan Islam terbentang dari wilayah Barat, yakni Andalusia, Afrika, sampai pada wilayah Timur, seperti Asia Tengah dan Timur Tengah, dari wilayahwilayah tersebut banyak terdapat tradisi intelektual dan peradaban yang tinggi dan cukup tua. Dari Luasnya daerah kekuasaan Islam memberikan ruang dialog keilmuan secara terbuka antara ilmuan muslim dengan ilmuan non muslim. Dengan banyaknya potensi keillmuan ini, dimanfaatkan dan dioptimalkan oleh khalifah di Bagdad tanpa memandang latar belakang agama dan etnis. Terbukti dengan adanya ilmuan muslim yang memiliki latar belakang berbeda yaitu Ibn Sina dari budaya Arab dan budaya Persia adalah Ar-Razi dan Al-

${ }^{9}$ Ibid., h. 51-52

${ }^{10}$ Joesoef Sou'yb, “Sejarah Daulat Abbasiyah”, (Jakarta : Bulan Bintang, 1977), h. 102

${ }^{11}$ Badri Yatim, "Sejarah Peradaban Islam", h. 52

12 Joesoef Sou'yb, “Sejarah Daulat Abbasiyah”, h. 102-103

${ }^{13}$ Mochamad Muksin, "Islam Dan Perkembangan Sains Dan Teknologi, Studi Perkembangan Sains Dan Teknologi Dinasti Abbasyiah", (Fakultas Teknologi Informasi, Universitas Negeri Malang : Jurnal Vol 2 , Nomor 4, 2016), h. 17

${ }^{14}$ Hasan Asari, “Menyingkap Zaman Keemasan Islam”, (Bandung : Mizan, 1994), h. 109 
Khawarismi dan lain sebagainya. Selain itu, hal ini juga bisa dilihat dari usaha Harun ArRasyid dalam melakukan pertukaran ilmu dengan kerajaan Romawi di Byzantium. ${ }^{15}$

\section{B.3 Masa Kepemimpinan Al-Ma'mun}

Amir Abdullah ibn Harun Ar-Rasyid atau yang dikenal dengan panggilan khalifah AlMa'mun adalah khalifah ke-6 pada masa pemerintahan dinasti Abbasiyah menggantikan ayahnya yang bernama Harun Ar-Rasyid. Di usia 28 tahun Al-Ma'mun memerintah dan menjadi khalifah pada tahun $813-833 \mathrm{M}$ atau kurang lebih selama 20 tahun ia berkuasa. ${ }^{16}$

Masa pemerintahannya juga memiliki peradaban dan kemajuan dalam bidang ilmu pengetahuan seperti halnya kemajuan yang dilahirkan oleh ayahnya yaitu Harun Ar-Rasyid khalifah ke-5 dinasti Abbasiyah. Usaha yang dilakukan sebagai wujud melanjutkan titah perjuangan dari sang ayah, di sisi lain ia juga mendapatkan sanjungan yang diabadikan dalam encyclopedia of world history yang disampaikan oleh William L. Langer, pada cetakan tahun 1956 di halaman 189 yang menuliskan bahwa : "masa pemerintahannya mungkin zaman paling gemilang di dalam sejarah khilafat. Kesustraan dan ilmiah dibantu perkembangannya dengan amat dermawan sekali. Dua buah Observatorium dibangun, sebuah di dekat Damascus dan sebuah lagi di dekat Bagdad gedung ilmu (Bait Al-Hikmah), berisikan perpustakaan yang amat kaya raya, dibangun di dekat gedung Observatorium. Bagdad karyakarya kesusastraan, ilmiah, filsafat, disalin dari bahasa Grik, Syiryani, Persia dan Sanskrit. ${ }^{17}$

Selain itu khalifah Al-Ma'mun juga dikenal sebagai khalifah yang sangat cinta kepada ilmu, terbukti pada masa pemerintahannya melakukan penerjemah buku-buku asing yang mulai digalakkan, mulai dari buku-buku Yunani dan ia juga banyak mendirikan sekolah, salah satu karya besarnya yang terpenting adalah mengembangkan dan membangun sedemikian rupa Bait Al-Hikmah kembali sehingga mampu maju dan terkenal, yang awalnya pada masa kepemimpinan Harun Ar-Rasyid adalah sebatas perpustakaan tetapi ditangan AlMa'mun difungsikan menjadi lembaga pendidikan dan juga sebagai pusat penerjemah yang berfungsi sebagai perguruan tinggi dengan kapasitas perpustakaan yang terbilang cukup besar. Pada masa inilah Bagdad mulai menjadi pusat kebudayaan dan ilmu pengetahun. ${ }^{18}$ Sedangkan untuk buku-buku yang banyak diterjemahkan adalah dalam bidang filsafat dan kedokteran. ${ }^{19}$

\section{B.4 Kebijakan Gerakan Penerjemah Sebagai Masa Kejayaan}

Khalifah-khalifah dinasti Abbasiyah diantaranya Harun Ar-Rasyid dan Al-Ma'mun secara terbuka mempelopori dan berkolaborasi untuk perkembangan ilmu pengetahuan dengan mendatangkan naskah-naskah kuno dari berbagai pusat peradaban sebelumnya yang kemudian diterjemahkan, diadaptasi dan diterapkan di Dunai Islam. Para ulama' muslim yang ahli dalam berbagai ilmu pengetahuan baik agama maupun non agama juga muncul pada masa ini.

Perkembangan sains pada masa Dinasti Abbasiyah selain gemilang pada masa pemerintahan khalifah Harun Al-Rasyid, juga mencapai kegemilangannya pada masa pemerintahan al-Makmun (813-833 M), yang mana pusatnya adalah di Bait Al-Hikmah. AlMakmun mengumpulkan berbagai ilmu pengetahuan yang berbahasa selain Arab, kemudian memerintahkannya untuk diterjemahkan ke dalam bahasa Arab. Pada zaman itulah muncul filosof Arab yang agung seperti al-Kindi yang telah menulis bebagai macam kitab ilmu

${ }^{15}$ Muqowim, “Genealogi Intelektual Saintis Muslim, Sebuah Kajian Tentang Pola Pengembangan Sains Dalam Islam Pada Periode Abbasyiah”, h. 6

16 Joesoef Sou'yb, "Sejarah Daulat Abbasiyah”, h. 145

${ }^{17}$ Ibid., h. 146

18 Badri Yatim, "Sejarah Peradaban Islam", h. 53

${ }^{19}$ Ibid., h. 56 
pengetahuan, al-Hajjaj bin Yusuf yang telah menterjemahkan untuk al-Makmun beberapa buah buku karya Euclides dan buku Ptolemy. ${ }^{20}$

Selain itu, dengan adanya proses asimilasi antar bangsa Arab dengan bangsa-bangsa lain yang lebih dahulu mengalami perkembangan dalam bidang ilmu pengetahuan. Pada masa pemerintahan Bani Abbas, bangsa-bangsa non-Arab banyak yang masuk Islam. Asimilasi berlangsung secara efektif dan bernilai guna. Di mana bangsa-bangsa ini memberi saham tertentu dalam perkembangan ilmu pengetahuan dalam Islam. Selain itu pengaruh Persia juga ikut andil dan banyak berjasa dalam perkembangan ilmu, filsafat dan sastra. ${ }^{21} \mathrm{Di}$ sisi lain pengaruh India juga bisa dilihat dalam bidang kedokteran, ilmu matematika dan astronomi. ${ }^{22}$ Sedangkan untuk pengaruh Yunani, masuk melalui terjemah-terjemah dalam banyak ilmu, terutama filsafat.

Untuk bidang keilmuan-keilmuan yang sudah berkembang melalui usaha penerjemah yang dilakukan oleh kedua khalifah tersebut, di Bagdad juga dibuka jasa penerjemahan. Bagi penerjemah buku-buku bahasa asing, akan dibayar dengan emas seberat buku yang diterjemahkan. ${ }^{23}$

Kemudian gerakan intensif dalam penerjemahan berbagai macam literatur yang dapat di bagi kedalam tiga fase. Pertama, yang berlangsung pada masa pemerintahan Al-Mansur menjadi khalifah sampai pemerintahan Harun Al-Rasyid. Pada fase ini yang banyak diterjemakan adalah karya-karya dalam bidang astronomi dan manthiq. Fase kedua berlangsung pada masa khalifah al-Makmun sampai tahun $300 \mathrm{H}$. Buku-buku yang banyak diterjemahkan adalah dalam bidang filsafat dan kedokteran. Fase ketiga berlangsung setelah tahun 300 hijriyah, terutama setelah adanya pembuatan kertas. Bidang-bidang ilmu yang diterjemahkan semakin meluas dibanding sebelumnya. ${ }^{24}$

Kota Bagdad sebagai pusat pemerintahan Harun Ar-Rasyid, dikenal dengan sebutan gudang intelektual yang tercatat dalam sejarah telah membangun sebuah perpustakaan sebagai pusat referensi ilmu pengetahuan dan tempat diskusi yang diberi nama "Baitul Hikmah" (gedung ilmu pengetahuan), yang kemudian dikembangkan menjadi lembaga pendidikan dan pusat penerjemah oleh putranya yaitu Al-Ma'mun, sebagai tindak lanjut atas usaha yang telah dipelopori oleh ayahnya. ${ }^{25}$

Pada tahun 830 M, Al-Ma'mun mendirikan darul hikmah atau akademi ilmu pengetahuan pertama di dunia, yaitu yang terdiri dari perpustakaan, pusat pemerintahan, observatorium bintang dan universitas (daru'l ulum). Selain itu sebagai tindak lanjut untuk mengembangkan ilmu pengetahuan, Al-Ma'mun mengirimkan serombongan penerjemah yaitu Abu Yahya ibn al-Batriq, Muhammad ibn Sallam, pemimpin daru'l hikmah Hajjaj ibn Yusuf ibn Mathar dan Hunayn ibn Ishak ke Konstantinopel, Roma dan lain-lain. ${ }^{26}$ Tugas mereka di sana adalah untuk memilih buku-buku pengetahuan yang belum dimiliki umat Islam untuk kemudian dibawa ke Bagdad untuk diterjemahkan, diteliti dan dibahas. Berkat usaha inilah banyak lahir ilmu pengetahuan dari kalangan Islam, baik yang sifatnya menambah dan memperkaya dari karya-karya asing yang telah ada dan diterjemahkan dalam bahasa Arab, di sisi lain juga ada ilmu baru yang lahir. Diantara sumbangan-sumbangan

20 Ahmad Syalabi, "Sejarah Dan Kebudayaan Islam-Iii Terjemahan Ast. Muhammad Labib Ahmad" (Jakarta : Pustaka Al Husna 1993), h. 137

${ }^{21}$ Ahmad Amin, "Dhuha Al-Islam”, (Kairo : Lajnah Al-Ta'lif Wa Al-Nasyr, Tanpa Tahun), H. 207

22 Ibid., h, 177-178

${ }^{23}$ Salmah Intan, “Kontribusi Dinasti Abbasiyah Bidang Ilmu Pengetahuan”, (Jurnal Rihlah Vol. 6 No.2 Tahun 2018), h. 168

${ }^{24}$ Ibid., h. 288-290

${ }^{25}$ Mochamad Muksin, "Islam Dan Perkembangan Sains Dan Teknologi, Studi Perkembangan Sains Dan Teknologi Dinasti Abbasyiah", h. 17

26 Poeradisastra, "Sumbangan Islam Kepada Ilmu Dan Peradaban Modern”, (Jakarta : Komunitas Bambu, 2008), h. 15 
kaum muslim kepada ilmu pengetahuan yaitu : ilmu pasti, fisika, kimia, farmasi, kedokteran, ilmu hayat, ilmu bintang dan ilmu bumi. Untuk yang berjasa besar dalam hal ini selaku penerjemah penting yaitu Hunayn ibn Ishak bersama dengan anaknya Ishak ibn Hanayn ibn Ishaq. ${ }^{27}$

Karya-karya Persia yang juga diterjemahkan pada masa kepemimpinan Harun ArRasyid oleh Al-Fadl ibn Nawbakht selaku kepala perpustakaan yang telah menerjemahkan beberapa karya astronomi dari Iran. ${ }^{28}$ Pusat penerjemah karya-karya asing yang telah dikumpulkan untuk kemudian diterjemahkan ke dalam bahsa Arab yaitu dilakukan di bait alhikmah sebuah perpustakan sekaligus tempat diskusi dan tempat belajar yang telah dibangun dan dikembangkan sebagai pusat pendidikan oleh khalifah Harun Ar-Rasyid dan Al-Ma'mun. di lembaga inilah buku-buku filsafat dan sains dari berbagai bahasa diterjemahkan. Dimuali ari karya-karya Palto, Aristoteles, Galen, Apolloniusm Archimedes dan lain-lain yang telah diterjemahkan dengan baik oleh Hunayn ibn Ishaq dan para penerjemah lainnya. ${ }^{29}$

Pada mulanya para penerjemah kebanyakan bukan dari kalangan orang Islam, tetapi pada periode berikutnya sudah mulai di handle dan diterjemahkan sendiri oleh orang Islam. Diantara para penerjemahnya berasal dari keluarga Barmak (Khurasan), orang-orang Zoroaster (Persia) dan para Kristen Nestoris (Syiria), mereka merupakan tenaga penerjemah yang digaji oleh khalifah Al-Ma'mun. Selain itu terdapat pula penerjemah lain dari orang Islam yaitu Abu Sahl Fazhl dan Alan Syu'ubi yang mana mereka berasal dari kebangsaan Persia, Yuhana (Jhon) ibn Masuya (Syiria) dan Qustha bin Luqa. ${ }^{30}$

Hasil dari gerakan penerjemahan ini yang selanjutnya bisa dinikmati oleh umat Islam terutamanya para kalangan intelektual dengan beberapa disiplin ilmu yang diminati. Di Kota Bagdad dalam melakukan gerakan terjemah bisa dilihat dari perkembangan ilmu pengetahuan umum, terutama pada bidang astronomi, kedokteran, filsafat, kimia dan sejarah. Pada abad ke-8 di Bagdad dan abad ke-9 di Andalusia, ketika itu ilmuan muslim melakukan transfer ilmu pengetahuan dari tradisi intelektual Yunani dan India ke dalam bahasa Arab yakni terjemahan dan translate dari bahasa Yunani dan Sansekerta ke dalam bahasa Arab, misalnya kata Plato ditransfer menjadi alfatun, Aristoteles menjadi aristu dan Hipocrates menjadi buqrat. ${ }^{31}$ Ketika dunia Islam sedang berada pada titik puncak kejayaan (the golden ages), sementara Barat berada pada masa kegelapan, sehingga pada abad ke-12 sampai pada abad ke-14, orang-orang Barat melakukan alih ilmu pengetahuan secara besar-besaran, dengan menerjemahkan teks-teks berbahasa Arab yang telah ditulis oleh ilmuan muslim, sehingga terjadi proses latinisasi dan banyak istilah ilmu pengatahuan yang diterjemahkan dari Arab ke bahasa Latin, misalnya alchemy dari kata al-kimiya, algoritma yang awalnya adalah alkhawarizm dan cipher yang asal katanya adalah sifr. ${ }^{32}$

Seorang tokoh iktizal Ibn an-Nadim (324-386 H/936-995 M, yang termasuk dalam periode kedua dan ketiga masa pemerintahan Abbasiyah atau yang disebut sebagai masa pengaruh Turki pertama dan masa kekuasaan dinasti Buwaih dalam pemerintahan khalifah Abbasiyah, yang disebut sebagai periode masa pengaruh Persia kedua), dalam karyanya $\mathrm{Al}$ Fihrist al-'Ulum yang tergolong dalam bibliografi terbesar, telah diwariskan penulisnya untuk kepemimpinan selanjutnya yang berada di dinasti Abbasiyah. Di mana karya ini berisi tentang catatan lengkap mengenai karya-karya ash beserta karya-karya Yunani, Parsi, India, Qibti dan Suryani yang telah diterjemahkan ke dalam bahasa Arab pada masa dinasti
${ }^{27}$ Ibid., h. 15-16
${ }^{28}$ Ibid., h. 132
${ }^{29}$ Ibid., h. 133
30 Ibid.
${ }^{31}$ Muqowim, “Genealogi Intelektual Saintis Muslim, Sebuah Kajian Tentang Pola Pengembangan Sains Dalam Islam Pada Periode Abbasyiah", h. 4
${ }^{32}$ Ibid., h. 3 
Abbasiyah. Selain itu juga, adapula seorang sarjana Kristen terkemuka di Mesir yaitu Jurji Zaidan (1861-1941), dalam karyanya yang berjudul Tarikhu't Tamadduni'l-Islami Jilid III, pada cetakan 1922 yang terdapat pada halaman 152-162, di terbitkan oleh Mathba'at-al Hilal di al Qahirah, yang mengambil dari karya al-fihrist mengenai karya-karya asing yang sudah diterjemahkan dalam bahasa Arab yang kemudian ditulisnya kembali beserta dengan namanama dari para penerjemahnya. Namun ada sebagian kecil yang tidak menyebutkan nama penerjemah pada karya terjemahannya. ${ }^{33}$

Untuk judul karya-karya yang telah diterjemahkan dalam bahasa Arab beserta dengan nama dari penerjemahnya akan dijabarkan dalam tulisan ini, yaitu sebagai berikut : ${ }^{34}$

\section{Tabel 1 ; Karya Hippocrates (464-357 pra-Masehi)}

Hippocrates adalah baak ilmu kedokteran di dunia yang berasal dari Thessalia, tetapi melakukan praktik dan mengajar di Athena. Ia meninggalkan beberapa karya yang kemudian diterjemahkan ke dalam bahasa Arab, diantaranya :

\begin{tabular}{|c|c|c|}
\hline No & Karya & Nama Penerjemah Beserta Keterangannya \\
\hline 1 & $\begin{array}{l}\text { Kitab Half Abqarath (Perihal } \\
\text { Sumpah Hippocrates) }\end{array}$ & $\begin{array}{l}\text { Hunayn ibn Ishaq yang telah menerjemahkan ke } \\
\text { dalam bahasa Suryani dan selanjutnya oleh } \\
\text { Hubaisy Al-Asam bersama 'Isa ibn Ibrahim } \\
\text { diterjemahkan ke dalam bahasa Arab. }\end{array}$ \\
\hline 2 & $\begin{array}{l}\text { Kitab Al-Fushuli (Perihal } \\
\text { Pergelangan) }\end{array}$ & $\begin{array}{l}\text { Hunayn ibn Ishaq yang dipersembahkan untuk } \\
\text { 'Amir Muhammad Ibn Musa }\end{array}$ \\
\hline 3 & $\begin{array}{l}\text { Kitab al Kasr (Perihal } \\
\text { Keretakan Tulang) }\end{array}$ & $\begin{array}{l}\text { Hunayn ibn Ishaq yang dipersembahkan untuk } \\
\text { 'Amir Muhammad Ibn Musa }\end{array}$ \\
\hline 4 & $\begin{array}{l}\text { Kitab Taqoddum'I Ma'rifat } \\
\text { (Perihal Pengantar bagi } \\
\text { Pengenalan) }\end{array}$ & $\begin{array}{l}\text { Hunayn ibn Ishaq bersama 'Isa ibn Yahya ibn } \\
\text { Ibrahim }\end{array}$ \\
\hline 5 & $\begin{array}{l}\text { Kitab Al-Amradhil Haddat } \\
\text { (Perihal Penyakit-penyakit } \\
\text { Gawat) }\end{array}$ & 'Isa ibn Yahya \\
\hline 6 & $\begin{array}{l}\text { Kitab Ibizimiva (Perihal } \\
\text { Penyakit Menular) }\end{array}$ & 'Isa ibn Yahya \\
\hline 7 & $\begin{array}{l}\text { Kitab al-Akhlath (Perihal } \\
\text { Cairan-cairan di dalam } \\
\text { Tubuh) }\end{array}$ & $\begin{array}{l}\text { 'Isa ibn Yahya atas permintaan 'Amir Muhammad } \\
\text { ibn Musa }\end{array}$ \\
\hline 8 & Kitab Qathitiun & $\begin{array}{l}\text { Hunayn ibn Ishaq atas permintaan 'Amir } \\
\text { Muhammad ibn Musa }\end{array}$ \\
\hline 9 & $\begin{array}{l}\text { Kitab al-Ma'wal Hawa } \\
\text { (Perihal Air dan Udara) }\end{array}$ & $\begin{array}{l}\text { Hunayn ibn Ishaq bersama dengan Hubbaisy ibn } \\
\text { al-A'sam }\end{array}$ \\
\hline 10 & $\begin{array}{l}\text { Kitab Thabi'atil-insan (Perihal } \\
\text { Tabiat-tabiat Manusia) }\end{array}$ & Hunayn ibn Ishaq bersama dengan 'Isa ibn Yahya \\
\hline
\end{tabular}

\footnotetext{
${ }^{33}$ Poeradisastra, “Sumbangan Islam Kepada Ilmu Dan Peradaban Modern”, h. 135
}

${ }^{34}$ Ibid., h. 136-151 


\section{Tabel 2 ; Karya-karya Kedokteran Lainnya}

Al-Fihrist mengatakan bahwa ada sejumlah kurang lebih dari 20 karya di bidang kedokteran diterjemahkan lagi ke dalam bahasa Arab. Karya Rufus, seorang ahli dari Kota Ephesos, tetapi tidak semua karyanya diterjemahkan ke dalam Bahasa Arab. Adapun 4 karya Orvasius yang diterjemahkan yaitu :

\begin{tabular}{|c|c|c|}
\hline No & Karya & Nama Penerjemah Beserta Keterangannya \\
\hline 1 & $\begin{array}{l}\text { Kitab al-Adwiyat al- } \\
\text { Musta'malat (Perihal Obat- } \\
\text { obatan yang Praktikal) }\end{array}$ & Stefanus ibn Basilius \\
\hline 2 & $\begin{array}{l}\text { Kitab as-Sab'in (Perihal Tujuh } \\
\text { Puluh) }\end{array}$ & $\begin{array}{l}\text { Hunayn ibn Ishaq bersama dengan 'Isa ibn Yahya } \\
\text { ke dalam bahasa Suryani }\end{array}$ \\
\hline 3 & $\begin{array}{l}\text { Kitab ill Ibnih Ifktitus (Surat } \\
\text { Kepada Puteranya Epictetus) }\end{array}$ & Hunayn ibn Ishaq \\
\hline 4 & $\begin{array}{l}\text { Kitab ila Abihi Artabius (Surat } \\
\text { kepada Bapaknya Artavius) }\end{array}$ & $\begin{array}{l}\text { Hunayn Ibn Ishaq, Selain Itu Terdapat Dua Karya } \\
\text { Dari } 2 \text { Tokoh Di Bidang Pengobatan Yang Telah } \\
\text { Diterjemahkan, Adapun Nama Kitab Dan } \\
\text { Penerjemahnya Yaitu: } \\
\text { 1. Kitab Al-Hasyaisy (Perihal Jenis-jenis Rumput } \\
\text { untuk Ramuan-ramuan atau Obat-obatan), } \\
\text { karya dari Dioscodorus, sedangkan untuk } \\
\text { nama penerjemahnya tidak dicatumkan pada } \\
\text { salinan kitabnya. } \\
\text { 2. Kitab al-Bursam (Perihal Uap Panas pada } \\
\text { Lapisan antara Jantung dan Hati), karya } \\
\text { Alexandros dan diterjemahkan oleh Yahya ibn } \\
\text { Batriq }\end{array}$ \\
\hline
\end{tabular}

Tabel 3 ; Karya Plato (427-347 pra-Masehi)

\begin{tabular}{|c|l|l|}
\hline No & \multicolumn{1}{|c|}{ Karya } & \multicolumn{1}{|c|}{ Nama Penerjemah Beserta Keterangannya } \\
\hline 1 & $\begin{array}{l}\text { Kitab as-Siyasat (Politea atau } \\
\text { bentuk Pemerintahan) }\end{array}$ & Hunayn ibn Ishaq yang bergelar Abu Zaid al-Ibadi \\
\hline 2 & $\begin{array}{l}\text { Kitab al-Munasabat (Perihal } \\
\text { Keseimbangan) }\end{array}$ & Yahya ibn Adiya \\
\hline 3 & $\begin{array}{l}\text { Kitab An-Nawarmis (Perihal } \\
\text { Hukum) }\end{array}$ & Hunayn ibn Ishaq dan Yahya ibn Adiya \\
\hline 4 & $\begin{array}{l}\text { Kitab Timius (Pericakapan } \\
\text { Socrates dengan Tinmaeus) }\end{array}$ & $\begin{array}{l}\text { Yitab Aflathun illa Aqritus } \\
\text { (Surat Plato kepada Critos) }\end{array}$ \\
\hline 6 & $\begin{array}{l}\text { Kitab At-Tauhid (Bagian Res } \\
\text { Publica atau urusan Publik } \\
\text { mengenai Illahiat) }\end{array}$ & Yahya ibn Adiya \\
\hline 7 & $\begin{array}{l}\text { Kitab al-Hasni wal-Lazzati } \\
\text { (Bagian Res Publica atau } \\
\text { urusan Publik mengenai } \\
\text { Kebajikan dan Kesenangan) }\end{array}$ & Tidak dicantumkan nama penerjemah nama penerjemah \\
\hline 8 & $\begin{array}{l}\text { Kitab Ushiili'l-Handasah } \\
\text { (Dasar-dasar Ilmu Ukur) }\end{array}$ & Qustha ibn Luqa \\
\hline
\end{tabular}


Tabel 4 ; Karya Aristotels (384-322 pra-Masehi

\begin{tabular}{|c|c|c|}
\hline No & Karya & Nama Penerjemah Beserta Keterangannya \\
\hline 1 & $\begin{array}{l}\text { Kitab Qathigyarias } \\
\text { (Categoriae) }\end{array}$ & $\begin{array}{l}\text { Hunayn ibn Ishaq, sedangkan Yahya ibn Bithriq } \\
\text { menerjemahkannya juga dengan judul Kitab } \\
\text { Maqulat al-'Asyarat yaitu bagian dari Organon } \\
\text { atau alat indra (himpunan bagian-bagian Logika) }\end{array}$ \\
\hline 2 & $\begin{array}{l}\text { Kitab al-Ibarat (De } \\
\text { Interpretatione) }\end{array}$ & $\begin{array}{l}\text { Hunayn ibn Ishaq ke dalam bahasa Suryani dan } \\
\text { puteranya Ishaq ibn Hunayn menerjemahkan ke } \\
\text { dalam bahasa Arab, yakni bagian Organon atau } \\
\text { alat indra. }\end{array}$ \\
\hline 3 & $\begin{array}{l}\text { Kitab Tahtili'l-Qias (Prior } \\
\text { Analyse) }\end{array}$ & $\begin{array}{l}\text { Theodorus bersama dengan Hunayn ibn Ishaq } \\
\text { yaitu bagian dari Organon atau alat indra. }\end{array}$ \\
\hline 4 & $\begin{array}{l}\text { Kitab al-Burhan (Posterior } \\
\text { Analyse) }\end{array}$ & $\begin{array}{l}\text { Ishaq ibn Hunayn ke dalam bahasa Suryani, } \\
\text { kemudian oleh Matta an-Nathuri diterjemahkan ke } \\
\text { dalam bahasa Arab, bagian Organon atau alat } \\
\text { indra. }\end{array}$ \\
\hline 5 & Kitab at-Jadal (Topics) & $\begin{array}{l}\text { Ishaq ibn Hunayn ke dalam bahasa Suryani, } \\
\text { kemudian oleh Yahya ibn Adiya diterjemahkan ke } \\
\text { dalam bahasa Arab, yakni bagian Organon atau } \\
\text { alat indra. }\end{array}$ \\
\hline 6 & $\begin{array}{l}\text { Kitab al-Mughulathat } \\
\text { (Sophistici Elenchi) }\end{array}$ & $\begin{array}{l}\text { Ibn Naimat dan Abu Bisyri ke dalam bahasa } \\
\text { Suryani, kemudian oleh Yahya ibn Ishaq } \\
\text { diterjemahkan ke dalam bahasa Arab, yakni } \\
\text { bagian Organon atau alat indra. }\end{array}$ \\
\hline 7 & Kitab al-Khithabat (Rhetorica) & $\begin{array}{l}\text { Ishaq ibn Hunayn ibn Ishaq dan Ibrahim ibn } \\
\text { 'Abdi'llah }\end{array}$ \\
\hline 8 & Kitab al-Syi'ri (Poetica) & $\begin{array}{l}\text { Abu Bisyri dari bahasa Suryani ke dalam bahasa } \\
\text { Arab. }\end{array}$ \\
\hline 9 & $\begin{array}{l}\text { Kitab al-Sama'ul-Thabi'I } \\
\text { (Physica) }\end{array}$ & $\begin{array}{l}\text { Abu Rush ash-Shabi, Hunayn ibn Ishaq, Yahya } \\
\text { ibn Adiya, Qustha ibn Luqa dan Ibn Naimat } \\
\text { dengan terjemah-terjemahnya sendiri. }\end{array}$ \\
\hline 10 & $\begin{array}{l}\text { Kitab As-Sama 'Wal-Alam (De } \\
\text { Caelo) }\end{array}$ & Yahya ibn Bathriq dan Hunayn ibn Ishaq \\
\hline 11 & $\begin{array}{l}\text { Kitab al-kaun wa'l-Fasad } \\
\text { (Generatione et Corruptione) }\end{array}$ & $\begin{array}{l}\text { Hunayn ibn Ishaq ke dalam bahasa Suryani } \\
\text { kemudian oleh puteranya Ishaq ibn Hunayn } \\
\text { bersama dengan ad-Damsyiqi diterjemahkan ke } \\
\text { dalam bahasa Arab. }\end{array}$ \\
\hline 12 & $\begin{array}{l}\text { Kitab al Atsarul-'Alawiyat } \\
\text { (Meteorologia) }\end{array}$ & $\begin{array}{l}\text { Abu Bisryi Matta ibn Yunus bersama dengan } \\
\text { Yahya ibn Adiya. }\end{array}$ \\
\hline 13 & Kitab an-Nafs (De Anima) & $\begin{array}{l}\text { Hunayn ibn Ishaq ke dalam bahasa Suryani } \\
\text { kemudian oleh puteranya Ishaq ibn Hunayn } \\
\text { diterjemahkan ke dalam bahasa Arab. }\end{array}$ \\
\hline 14 & $\begin{array}{l}\text { Kitab al-Hassi wal-Mahsus } \\
\text { (Parwa Naturalia) }\end{array}$ & Abu Bisyri Matta ibn Yunus \\
\hline 15 & $\begin{array}{l}\text { Kitab al-Hayawan (Historia } \\
\text { Animalium) }\end{array}$ & Yahya ibn Bathriq \\
\hline 16 & Kitab al-Akhlaq (Ethica) & Ishaq ibn Hunayn \\
\hline
\end{tabular}




\begin{tabular}{|c|l|l|}
\hline 17 & Kitab al-Illahiyat (Theodicea) & $\begin{array}{l}\text { Ishaq ibn Hunayn, Yahya ibn Adiyat, Hunayn ibn } \\
\text { Ishaq dan Abu Bisyri Matta ibn Yunus dengan } \\
\text { terjemah-terjemahnya sendiri. }\end{array}$ \\
\hline 18 & $\begin{array}{l}\text { Kitab al-Miratu (Kedudukan } \\
\text { Wanita) }\end{array}$ & Al-Hajjaj ibn Maththar. \\
\hline
\end{tabular}

Tabel 5 ; Karya Euclides (Lebih dari 300 pra-Masehi

Euclides adalah seorang ahli ilmu ukur dan ilmu pasti dari Yunani purba yang hidup kurang lebih pada abad ke-3 pra-Masehi dan meninggalkan beberapa karya yang sempat diterjemahkan ke dalam bahasa Arab.

\begin{tabular}{|c|l|l|}
\hline No & \multicolumn{1}{|c|}{ Karya } & \multicolumn{1}{|c|}{ Nama Penerjemah Beserta Keterangannya } \\
\hline 1 & $\begin{array}{l}\text { Kitab Ushuli'l-Handasat } \\
\text { (Perihal Dasar-dasar Ilmu } \\
\text { Ukur) }\end{array}$ & $\begin{array}{l}\text { Hajjaj ibn Yusuf ibn Mathar, yang } \\
\text { dipersembahkan untuk khalifah Harun Ar-Rasyid } \\
\text { dan Al-Ma'mun, selain itu diterjemahkan pula } \\
\text { oleh Ishaq ibn Hunayn dan diperbaiki oleh Tsabit } \\
\text { ibn Qurra, kemudian diterjemahkan lagi oleh Abu } \\
\text { 'Utsman ad-Damsyiqi. }\end{array}$ \\
\hline 2 & $\begin{array}{l}\text { Kitab azh-Zhahirat (Perihal } \\
\text { Gejala-gejala) }\end{array}$ & Tidak dicantumkan nama penerjemah \\
\hline 3 & $\begin{array}{l}\text { Kitab Ikhtilafi Munazhiri } \\
\text { (Perihal Perbedaan Titik } \\
\text { Pandang) }\end{array}$ & Tidak dicantumkan nama penerjemah \\
\hline 4 & $\begin{array}{l}\text { Kitab al-Musiqi (Perihal } \\
\text { Nada-nada Musik) }\end{array}$ & $\begin{array}{l}\text { Tidak dicantumkan nama penerjemah } \\
\text { Mitab al-Qismat (Perihal }\end{array}$ \\
\hline 6 & $\begin{array}{l}\text { Kitab al-Qanun (Perihal } \\
\text { Hukum-Qanun=Pokok) }\end{array}$ & Tidak dicantumkan nama penerjemah \\
\hline 7 & $\begin{array}{l}\text { Kita bats-Tsiql wal-khiffat } \\
\text { (Perihal Berat dan Ringan) }\end{array}$ & Tidak dicantumkan nama penerjemah \\
\hline
\end{tabular}

Tabel 6 ; Berbagai Karya Lainnya

3 buah karya Klaudios Ptolemalos (87-168 M), ahli bintang, ilmu pasti dan ilmu bumi yang termasyhur, diantaranya yaitu :

\begin{tabular}{|c|l|l|}
\hline No & \multicolumn{1}{|c|}{ Karya } & \multicolumn{1}{|c|}{ Nama Penerjemah Beserta Keterangannya } \\
\hline 1 & Kitab al-Majisthi & $\begin{array}{l}\text { Yahya al-Barmaki yang menerjemahkan mengenai } \\
\text { sistem ilmu bintang yang terpandang besar masa } \\
\text { itu dan sewaktu diterjemahkan kembali dalam } \\
\text { bahasa latin disebut Almagest. }\end{array}$ \\
\hline 2 & $\begin{array}{l}\text { Kitab al-Arba'at (Himpunan } \\
\text { Empat Buah Karya) }\end{array}$ & $\begin{array}{l}\text { Ibrahim ibn Shalti dan diperbaiki oleh Hunayn ibn } \\
\text { Ishaq }\end{array}$ \\
\hline 3 & $\begin{array}{l}\text { Kitab Jughrafatil Ma'mur wa } \\
\text { Shifatil-Ardh (Perihal Ilmu } \\
\text { Bumi Daerah Berpenghuni } \\
\text { Beserta Sifat-sifat Bumi. }\end{array}$ & Tsabit ibn Qurrah. \\
\hline
\end{tabular}

\section{Tabel 7 ; Karya-karya Galenos}

Claudios Galenos merupakan seorang tabib termasyhur, ahli ilmu urai dan ilmu fa'al (salah satu dari cabang-cabang biologi yang mempelajari berlangsungnya sistem kehidupan) dan menjabat sebagai tabib istana pada Kaisar Marcus Aurelius (161-180 M) serta kaisar kemaharajaan Roma. Banyak karyanya di bidang ilmu kedokteran dan filsafat, 
yang sebagian besar telah diterjemahkan ke dalam bahasa Arab. Dalam bidang filsafat diantaranya sebagai berikut :

\begin{tabular}{|c|c|c|}
\hline No & Karya & Nama Penerjemah Beserta Keterangannya \\
\hline 1 & $\begin{array}{l}\text { Kitab ma-Ya'taqidah (Tentang } \\
\text { Aqidah Galenos) }\end{array}$ & Tsabit ibn Qurrah \\
\hline 2 & $\begin{array}{l}\text { Kitab Ta'rif al-Mar'i 'Uyuba } \\
\text { Nafsih (Mengenali Titik-titik } \\
\text { Lemah pada Manusia) }\end{array}$ & Tomas dan Hunayn ibn Ishaq \\
\hline 3 & $\begin{array}{l}\text { Kitab Al-Alaq (Tentang Nilai- } \\
\text { nilai) }\end{array}$ & Hubbasisy ibn al-A'sam \\
\hline 4 & $\begin{array}{l}\text { Kitab Intifa'il Akhyar Bi } \\
\text { A'daihim (Bagaimana } \\
\text { Mengambil Manfaat dari } \\
\text { Musuh) }\end{array}$ & Hubbasisy ibn al-A'sam \\
\hline 5 & $\begin{array}{l}\text { Kitab Muharrik Awal La } \\
\text { Yataharak (Perihal Primum } \\
\text { Mobilum Immotum Yaitu } \\
\text { Penggerak Pertama yang Zat- } \\
\text { zatnya Sendiri tidak Bergerak) }\end{array}$ & Isa ibn Yahya ibn Ibrahim \\
\hline 6 & $\begin{array}{l}\text { Kitab al-Usthuqshat (Perihal } \\
\text { Unsur-unsur Asal) }\end{array}$ & Hunayn ibn Ishaq \\
\hline 7 & $\begin{array}{l}\text { Kitab Ulmu Aristhu (Perihal } \\
\text { Karya-karya Ilmiah } \\
\text { Aristoteles) }\end{array}$ & Hunayn ibn Ishaq \\
\hline 8 & $\begin{array}{l}\text { Kitab Al-adat (Perihal Ragam- } \\
\text { ragam Tradisi) }\end{array}$ & Hunayn ibn Ishaq \\
\hline 9 & $\begin{array}{l}\text { Kitab i’la Traqubulus (Surat } \\
\text { Kepada Tracopollos) }\end{array}$ & Hunayn ibn Ishaq \\
\hline 10 & $\begin{array}{l}\text { Kitab At-Thabib wal Failsasuf } \\
\text { (Kitab Dokter-dokter dan } \\
\text { Filsuf-filsuf) }\end{array}$ & Hunayn ibn Ishaq \\
\hline 11 & $\begin{array}{l}\text { Kitab Aflathuni fi Timius } \\
\text { (Pokok-pokok Pikiran Plato di } \\
\text { dalam Timaeus) }\end{array}$ & Hunayn ibn Ishaq dan puteranya Ishaq bin Hunayn \\
\hline \multicolumn{3}{|c|}{ Sedangkan untuk karya-karya Galegos di bidang kedokteran yaitu sebagai berikut } \\
\hline No & Karya & Nama Penerjemah Beserta Keterangannya \\
\hline 1 & $\begin{array}{l}\text { Kitab al-Faruq (Perihal } \\
\text { Kejutan Keras) }\end{array}$ & Hunayn ibn Ishaq \\
\hline 2 & $\begin{array}{l}\text { Kitab ash-Shina'at (Perihal } \\
\text { Praktik) }\end{array}$ & Hunayn ibn Ishaq \\
\hline 3 & $\begin{array}{l}\text { Kitab an-Nabadhi (Perihal } \\
\text { Getaran Hati) }\end{array}$ & Hunayn ibn Ishaq \\
\hline 4 & $\begin{array}{l}\text { Kitab Syifail-Amradh (Perihal } \\
\text { Penyembuhan Penyakit) }\end{array}$ & Hunayn ibn Ishaq \\
\hline 5 & $\begin{array}{l}\text { Kitab al-Maqalatil-Khams } \\
\text { (Kumpulan Lima Bahasan) }\end{array}$ & Hunayn ibn Ishaq \\
\hline 6 & Kitab al-Mijaz (Perihal & Hunayn ibn Ishaq \\
\hline
\end{tabular}




\begin{tabular}{|c|c|c|}
\hline & Susunan Tubuh) & \\
\hline 7 & $\begin{array}{l}\text { Kitab al-Quwath Thabi'iyat } \\
\text { (Perihal Kekuatan-kekuatan } \\
\text { Ilmiah) }\end{array}$ & Hunayn ibn Ishaq \\
\hline 8 & $\begin{array}{l}\text { Kitab al-Ilal wal Amradh } \\
\text { (Perihal Sebab-sebab dan } \\
\text { Penyakit) }\end{array}$ & Hunayn ibn Ishaq \\
\hline 9 & $\begin{array}{l}\text { Kitab Ta'aruf Illati A'dhail- } \\
\text { Bathinat (Cara Mengenali } \\
\text { Sebab-sebab Penyakit pada } \\
\text { Anggota Tubuh sebelum } \\
\text { Makan) }\end{array}$ & Hunayn ibn Ishaq \\
\hline 10 & $\begin{array}{l}\text { Kitab an-Nabhadil Akbar } \\
\text { (Uraian Lebih Lengkap } \\
\text { mengenai Getaran Hati) }\end{array}$ & Hubbaisy al-'Asam \\
\hline 11 & $\begin{array}{l}\text { Kitab al-Himayat (Berbagai } \\
\text { Ragam Demam Panas) }\end{array}$ & Hunayn ibn Ishaq \\
\hline 12 & $\begin{array}{l}\text { Kitab Al-Burhan (Perihal } \\
\text { Cedera Pada Alat Tanggapan) }\end{array}$ & Hunayn ibn Ishaq \\
\hline 13 & $\begin{array}{l}\text { Kitab Tadbiril Ashihah } \\
\text { (Perihal Pengaturan } \\
\text { Kesehatan) }\end{array}$ & Hubbaisy al-'Asam \\
\hline 14 & $\begin{array}{l}\text { Kitab Ayyamil Buhran (Perihal } \\
\text { Saat-saat Kecederaan Alat } \\
\text { Tanggapan) }\end{array}$ & Hunayn ibn Ishaq \\
\hline 15 & $\begin{array}{l}\text { Kitab At-Tasyrihil-Kabir } \\
\text { (Uraian Lengkap Tentang } \\
\text { Pembedahan) }\end{array}$ & Hubbaisy al-'Asam \\
\hline 16 & $\begin{array}{l}\text { Kitab Ikhtilafil-Tasyirih (Buku } \\
\text { Ragam-ragam Pembedahan) }\end{array}$ & Hubbaisy al-'Asam \\
\hline 17 & $\begin{array}{l}\text { Kitab at-Tasyrihil Hayawanil } \\
\text { Hayy (Perihal Pembedahan } \\
\text { Hewan Hidup) }\end{array}$ & Hubbaisy al-'Asam \\
\hline 18 & $\begin{array}{l}\text { Kitab at-Tasyrihil Hayawanil } \\
\text { Mayyit (Perihal Pembedahan } \\
\text { Hewan Mati) }\end{array}$ & Hubbaisy al-'Asam \\
\hline 19 & $\begin{array}{l}\text { Kitab al-Ilmu Abqarath bi't- } \\
\text { Tasyirih (Perihal Pembedahan } \\
\text { Hippocrates mengenai } \\
\text { Pembedahan) }\end{array}$ & Hubbaisy al-'Asam \\
\hline 20 & $\begin{array}{l}\text { Kitab Al-Hajati Ila N'-Nabadhi } \\
\text { (Perihal Keperluan akan } \\
\text { Getaran Hati) }\end{array}$ & Hubbaisy al-'Asam \\
\hline 21 & $\begin{array}{l}\text { Kitab Ara'i Abqarath wa } \\
\text { Aflathuni (Perihal Pokok- } \\
\text { pokok Pikiran Hipocrates dan } \\
\text { Plato) }\end{array}$ & Hubbaisy al-'Asam \\
\hline 22 & $\begin{array}{l}\text { Kitab Khashbi'l-Badan } \\
\text { (Perihal Kesuburan Badan) }\end{array}$ & Hubbaisy al-'Asam \\
\hline
\end{tabular}




\begin{tabular}{|c|c|c|}
\hline 23 & $\begin{array}{l}\text { Kitab Manafi'il A'dha-i } \\
\text { (Perihal Kegunaan Anggota } \\
\text { Tubuh) }\end{array}$ & Hubbaisy al-'Asam \\
\hline 24 & $\begin{array}{l}\text { Kitab Tarkibil Adawiyat } \\
\text { (Perihal Ramu-ramuan Obat- } \\
\text { obatan) }\end{array}$ & Hubbaisy al-'Asam \\
\hline 25 & $\begin{array}{l}\text { Kitab ar-Rhiyadat bil Kurratil } \\
\text { Shagirah (Perihal Latihan } \\
\text { dengan Bola Kecil) }\end{array}$ & Hubbaisy al-'Asam \\
\hline 26 & $\begin{array}{l}\text { Kitab ar-Rhiyadat bil } \\
\text { Kurratil'l-Kabirah (Perihal } \\
\text { Latihan dengan Bola Besar) }\end{array}$ & Hubbaisy al-'Asam \\
\hline 27 & $\begin{array}{l}\text { Kitab al-Hatsi 'ala Ta'limith } \\
\text { Thibb (Rangsangan untuk } \\
\text { Mempelajari Ilmu } \\
\text { Kepercayaan) }\end{array}$ & Hubbaisy al-'Asam \\
\hline 28 & $\begin{array}{l}\text { Kitab Quwal-Nafs (Perihal } \\
\text { Kekuatan-kekuatan Jiwa dan } \\
\text { Susunan Badan) }\end{array}$ & Hubbaisy al-'Asam \\
\hline 29 & $\begin{array}{l}\text { Kitab Harkatish-Shadr } \\
\text { (Perihal Gerak-gerik Dada) }\end{array}$ & Stefanus dengan bantuan Hunayn Ibn Ishaq \\
\hline 30 & $\begin{array}{l}\text { Kitab 'ilalin-Nafs (Perihal } \\
\text { Sebab-sebab Penyakit Jiwa) }\end{array}$ & Stefanus dengan bantuan Hunayn Ibn Ishaq \\
\hline 31 & $\begin{array}{l}\text { Kitab Harkatil Adhali (Perihal } \\
\text { Getaran pada Lengan) }\end{array}$ & Stefanus bersama Hunayn Ibn Ishaq \\
\hline 32 & $\begin{array}{l}\text { Kitab al-Hajati ila'n-Nafas } \\
\text { (Perihal Keperluan } \\
\text { Pernafasan) }\end{array}$ & Stefanus bersama Hunayn Ibn Ishaq \\
\hline 33 & $\begin{array}{l}\text { Kitab al-Imtilak (Perihal Usia } \\
\text { Panjang) }\end{array}$ & Stefanus bersama Hunayn Ibn Ishaq \\
\hline 34 & $\begin{array}{l}\text { Kitab al-Mirrati wa's-Sauda } \\
\text { (Perihal Paduan Kuning dan } \\
\text { Hitam pada Tubuh) }\end{array}$ & Stefanus bersama Hunayn Ibn Ishaq \\
\hline 35 & $\begin{array}{l}\text { Kitab al-Harkat'l-Majhulat } \\
\text { (Perihal Getaran-getaran yang } \\
\text { tidak dikenali) }\end{array}$ & Hunayn Ibn Ishaq \\
\hline 36 & $\begin{array}{l}\text { Kitab 'Ilali'sh-Shauti (Perihal } \\
\text { Sebab-sebab Cedera pada } \\
\text { Suara) }\end{array}$ & Hunayn Ibn Ishaq \\
\hline 37 & $\begin{array}{l}\text { Kitab Afdhalil-Hay'ah (Perihal } \\
\text { Benda-benda Langit) }\end{array}$ & Hunayn Ibn Ishaq \\
\hline 38 & $\begin{array}{l}\text { Kitab Sui'l-Mizajil-Mukhtalafi } \\
\text { (Perihal Keburukan pada } \\
\text { Susunan yang Tidak Selaras) }\end{array}$ & Hunayn Ibn Ishaq \\
\hline 39 & $\begin{array}{l}\text { Kitab al-Adwiyat al-Mufradah } \\
\text { (Perihal Perincian Obat- } \\
\text { obatan) }\end{array}$ & Hunayn Ibn Ishaq \\
\hline 40 & $\begin{array}{l}\text { Kitab al-Maulud li Sab'ati } \\
\text { Asyhur (Perihal Bayi yang }\end{array}$ & Hunayn Ibn Ishaq \\
\hline
\end{tabular}




\begin{tabular}{|c|c|c|}
\hline & Terlahir Sewaktu Tujuh Bulan) & \\
\hline 41 & $\begin{array}{l}\text { Kitab Ridaati Tanaffusi } \\
\text { (Perihal Pernafasan yang } \\
\text { Bergasau) }\end{array}$ & Hunayn Ibn Ishaq \\
\hline 42 & $\begin{array}{l}\text { Kitab az-Zabuli (Perihal } \\
\text { Kekeringan pada } \\
\text { Kerongkongan) }\end{array}$ & Hunayn Ibn Ishaq \\
\hline 43 & $\begin{array}{l}\text { Kitab Quwal Aghziyat (Perihal } \\
\text { Kekuatan Pencernaan) }\end{array}$ & Hunayn Ibn Ishaq \\
\hline 44 & $\begin{array}{l}\text { Kitab at-Tadbiril Mulattaf } \\
\text { (Perihal Susunan Saraf-saraf } \\
\text { Halus) }\end{array}$ & Hunayn Ibn Ishaq \\
\hline 45 & $\begin{array}{l}\text { Kitab Abqarathi fi'l-Amradhil- } \\
\text { Haddat (Perihal Pendapat } \\
\text { Hippocrates mengenai } \\
\text { Panyakit-penyakit yang } \\
\text { Gawat) }\end{array}$ & Hunayn Ibn Ishaq \\
\hline 46 & $\begin{array}{l}\text { Kitab Abraqathish-Shihhiyat } \\
\text { (Karya-karya Hippocrates di } \\
\text { Bidang Kesehatan) }\end{array}$ & Hunayn Ibn Ishaq \\
\hline 47 & $\begin{array}{l}\text { Kitab Mihnati'th-Thabib } \\
\text { (Perihal Terapi Seorang } \\
\text { Dokter }\end{array}$ & Hunayn Ibn Ishaq \\
\hline 48 & $\begin{array}{l}\text { Kitab al-Fashdi (Perihal } \\
\text { Pengisapan Darah Kotor } \\
\text { melalui Pembekaman) }\end{array}$ & Isa ibn Yahya bersama Stefanus \\
\hline 49 & $\begin{array}{l}\text { Kitab Shifat li Shabiy Yashrakh } \\
\text { (Perihal Sifat-sifat Bayi yang } \\
\text { Menjerit) }\end{array}$ & Ibrahim ibn Shalti \\
\hline 50 & $\begin{array}{l}\text { Kitab al-Awram (Perihal } \\
\text { Sebab-sebab Berangasan) }\end{array}$ & Ibrahim ibn Shalti \\
\hline 51 & Kitab al-Kaimus & Tsabit ibn Qurra bersama Hubbaisy al-A'sam \\
\hline 52 & $\begin{array}{l}\text { Kitab al-Adwiyat wa'l-Adwa } \\
\text { (Perihal Obat-obatan dan } \\
\text { Penyakit) }\end{array}$ & Isa ibn Ibrahim \\
\hline 53 & $\begin{array}{l}\text { Kitab at-Tiryaq (Perihal Obat } \\
\text { Keracunan) }\end{array}$ & Yahya bin Batriq \\
\hline
\end{tabular}

Tabel 8 ; Karya-karya Pahlevi Purba dan Iran

Bahasa Pahlevi adalah perpaduan antara bahasa Yunani dengan parsi purba, selain itu bahasa Pahlevi kaya dengan kesusastraan dan pada masa bani Abbasiyah berlangsung penerjemahan ke dalam bahasa Arab, diantara karya-karya terpentingnya yaitu :

\begin{tabular}{|c|l|l|}
\hline No & \multicolumn{1}{|c|}{ Karya } & Nama Penerjemah Beserta Keterangannya \\
\hline 1 & $\begin{array}{l}\text { Kitab Rustam wa Isfandiar } \\
\text { (kisah pahlawan Rustam yang } \\
\text { sangat terkenal di Iran) }\end{array}$ & Jabalah ibn Salim \\
\hline 2 & $\begin{array}{l}\text { Kitab Bahram Syussya (kisah } \\
\text { kepahlawanan Bahram dari } \\
\text { Kota Sussa) }\end{array}$ & Jabalah ibn Salim \\
\hline 3 & Kitab Khudainameh fi's-Sair & Abdullah ibn Muqaffa \\
\hline
\end{tabular}




\begin{tabular}{|c|c|c|}
\hline 4 & Kitab Abennameh & Abdullah ibn Muqaffa \\
\hline 5 & $\begin{array}{l}\text { Kitab Kalilah wa Dimnah } \\
\text { (kisah kiasan dari India) }\end{array}$ & Abdullah ibn Muqaffa \\
\hline 6 & Kitab Mazdak & Abdullah ibn Muqaffa \\
\hline 7 & $\begin{array}{l}\text { Kitab at-Taj fi'Sairati } \\
\text { Anusyirwan (kisah Khusyrau } \\
\text { Anusyirwan Adil) }\end{array}$ & Abdullah ibn Muqaffa \\
\hline 8 & $\begin{array}{l}\text { Kitab al-'Adabil Kabir (Buku } \\
\text { Sastra Besar) }\end{array}$ & Abdullah ibn Muqaffa \\
\hline 9 & $\begin{array}{l}\text { Kitab al-'Adabil Shagir (Buku } \\
\text { Sastra Kecil) }\end{array}$ & Abdullah ibn Muqaffa \\
\hline 10 & $\begin{array}{l}\text { Kitab al-Yatimah (kisah } \\
\text { seorang Anak Yatim) }\end{array}$ & Abdullah ibn Muqaffa \\
\hline 11 & $\begin{array}{l}\text { Kitab Syahrazad wa Abarwiz } \\
\text { (Kisah Syahrazad dan Khosrau } \\
\text { Parviz) }\end{array}$ & $\begin{array}{l}\text { Abdullah ibn Muqaffa yang kemudian dijadikan } \\
\text { landasan kisah seribu satu malam }\end{array}$ \\
\hline 12 & $\begin{array}{l}\text { Kitab al-Karnamij Anusyirwan } \\
\text { (kisar sekitar diri Khosrau } \\
\text { Anusyirwan Adil) }\end{array}$ & Abdullah ibn Muqaffa \\
\hline 13 & $\begin{array}{l}\text { Kitab a'd-Daria wa'sh } \\
\text { Shanamil Zahbi (Kisah Darius } \\
\text { III dengan Patung Emas) }\end{array}$ & Abdullah ibn Muqaffa \\
\hline 14 & $\begin{array}{l}\text { Kitab Bahram wa Narsi (Kisah } \\
\text { Pahlawan Bahram berhadapan } \\
\text { dengan pahlawan Yunani } \\
\text { Narcius) }\end{array}$ & Abdullah ibn Muqaffa \\
\hline 15 & Kitab Hazardistan & Abdullah ibn Muqaffa \\
\hline 16 & $\begin{array}{l}\text { Kitab Sairi Mulukil-Parsi } \\
\text { (berisikan sejarah raja-raja } \\
\text { Parsi) }\end{array}$ & $\begin{array}{l}\text { Muahmmad ibn Jahham al-Barmaki, Zadaweh ibn } \\
\text { Syahweh dan Muhammad ibn Bahram ibn } \\
\text { Mathiyar. }\end{array}$ \\
\hline
\end{tabular}

Tabel 9 ; Karya-karya Sanskrit dari India

Penerjemah karya-karya Sanskrit dari India yang dipandang giat adalah Maniaka alHindi. Ia adalah seorang dokter yang awalnya diundang oleh Wazir Yahya al-Barmaki (Gubernur Wilayah Sind/Pakistan Sekarang) untuk mengobati Khalifah Harun Ar-rasyid. Dengan kemampuan dan keberhasilannya menyembuhkan Harun Ar-Rasyid, yang kemudian diberikan sebuah hadiah dan anugerah untuk menerjemahkan karya-karya Sanskrit.

Seorang tokoh-tokoh lain yang juga datang ke Bagdad pada masa khalifah Harun Ar-Rasyid untuk menjadi penerjemah diantaranya Shalih ibn Bahlat al-Hindi, Syanaq alHindi, Ishaq ibn Sulaiman dan Ibnu Dhani al-Farsi

Al-Fihrist mencatat karya-karya Sanskrit yang diterjemahkan ke dalam bahasa Arab diantaranya karya dalam bidang kedokteran yaitu :

\begin{tabular}{|c|l|l|}
\hline No & \multicolumn{1}{|c|}{ Karya } & Nama Penerjemah Beserta Keterangannya \\
\hline 1 & $\begin{array}{l}\text { Kitab Sardi Fi'th-Thibb } \\
\text { (mengenai urutan di dalam } \\
\text { ilmu kedokteran) }\end{array}$ & Maniaka al-Hindi \\
\hline 2 & $\begin{array}{l}\text { Kitab Asmai'Aqaqir al-Hindi } \\
\text { (mengenai jenis-jenis ramuan } \\
\text { di India) }\end{array}$ & Ishaq ibn Sulaiman \\
\hline
\end{tabular}




\begin{tabular}{|c|c|c|}
\hline 3 & Kitab Istankar al-Jamik & Ibnu Dhani \\
\hline 4 & $\begin{array}{l}\text { Kitab Shafwati'n-Najah } \\
\text { (perihal kebahagian yang } \\
\text { murni) }\end{array}$ & Ibnu Dhani \\
\hline 5 & $\begin{array}{l}\text { Kitab Mukhtasharil fi'l-Aqaqiri } \\
\text { (Ikhtisar mengenai Ramu- } \\
\text { ramuan obat di India) }\end{array}$ & Tidak dicantumkan nama penerjemah \\
\hline 6 & $\begin{array}{l}\text { Kitab Hajatil Hubala fi'l-Hindi } \\
\text { (cara perawatan perempuan } \\
\text { hamil di India) }\end{array}$ & Tidak dicantumkan nama penerjemah \\
\hline 7 & $\begin{array}{l}\text { Kitab ar-Rusal Hindiyati } \\
\text { fi'Ilaja ti'n-Nisa'I (mengenai } \\
\text { rempah-rempah India bagi } \\
\text { pengobatan kaum perempuan) }\end{array}$ & Tidak dicantumkan nama penerjemah \\
\hline 8 & $\begin{array}{l}\text { Kitab at-Tawahhumi fi'l- } \\
\text { Amradhi wal-'Ilal (tentang } \\
\text { pengaruh prasangka terhadap } \\
\text { penyakit dan sebab penyakit) }\end{array}$ & Tidak dicantumkan nama penerjemah \\
\hline 9 & $\begin{array}{l}\text { Kitab a's-Sakri fi'l-Hindi } \\
\text { (mengenai penyakit gula di } \\
\text { India) }\end{array}$ & Tidak dicantumkan nama penerjemah \\
\hline 10 & $\begin{array}{l}\text { Kitab Rakyil-Hindi fi'Ajnasi } \\
\text { Hayyati wa Samumiha } \\
\text { (mengenai pokok-pokok } \\
\text { pendapat di India tentang } \\
\text { bermacam-macam Ular dan } \\
\text { Jenis bisanya) }\end{array}$ & Tidak dicantumkan nama penerjemah \\
\hline \multicolumn{3}{|c|}{$\begin{array}{l}\text { Selain karya-karya di bidang kedokteran di atas, terdapat pula terjemahan karya- } \\
\text { karya di bidang kesusastraan dan filsafat diantaranya yaitu : }\end{array}$} \\
\hline No & Karya & Nama Penerjemah Beserta Keterangannya \\
\hline 1 & $\begin{array}{l}\text { Kitab Kalila wa Dimnah } \\
\text { (kisah-kisah terkenal dari } \\
\text { bahasa Sanskrit) }\end{array}$ & Abdullah ibn Muqaffa \\
\hline 2 & $\begin{array}{l}\text { Kitab Sinbad ash-Shaghir } \\
\text { (kisah petualangan Sinbad } \\
\text { Muda) }\end{array}$ & Tidak dicantumkan nama penerjemah \\
\hline 3 & $\begin{array}{l}\text { Kitab Sinbad al-Kabir (kisah } \\
\text { Pelaut Sinbad tua) }\end{array}$ & Yang menjadi landasan kisah 1001 malam \\
\hline 4 & $\begin{array}{l}\text { Kitab al-Buda (uraian } \\
\text { mengenai Buddha Darma) }\end{array}$ & Tidak dicantumkan nama penerjemah \\
\hline 5 & $\begin{array}{l}\text { Kitab Yuzafis (kisah } \\
\text { petualangan) }\end{array}$ & Tidak dicantumkan nama penerjemah \\
\hline 6 & $\begin{array}{l}\text { Kitab al-Adab al-Hindi wa'sh- } \\
\text { Shini (buku sastra India dan } \\
\text { Tiongkok) }\end{array}$ & Tidak dicantumkan nama penerjemah \\
\hline 7 & $\begin{array}{l}\text { Kita bath-Thuruq (mengenai } \\
\text { beragam aliran mistik/thariqat }\end{array}$ & Tidak dicantumkan nama penerjemah \\
\hline
\end{tabular}




\begin{tabular}{|c|l|l|}
\hline & $\begin{array}{l}\text { di India, baik di dalam agama } \\
\text { Hindu maupun Buddha Darma }\end{array}$ & \\
\hline 8 & $\begin{array}{l}\text { Kitab al-Hindi fi'Qishshati } \\
\text { hubuthi Adam (kisah India } \\
\text { mengenai manusia pertama } \\
\text { dan kejatuhannya) }\end{array}$ & Tidak dicantumkan nama penerjemah \\
\hline 9 & $\begin{array}{l}\text { Kitab Baidaba fi'l-Hikmat } \\
\text { (mengenai pokok-pokok } \\
\text { pikiran Baidaba (Vaisnawa) di } \\
\text { bidang hikmah kearifan) }\end{array}$ & Tidak dicantumkan nama penerjemah \\
\hline 10 & $\begin{array}{l}\text { Kitab Hududi Manthiq al- } \\
\text { Hindi (mengenai perbatasan } \\
\text { wilayah anak benua India } \\
\text { beserta macam-macam } \\
\text { penduduknya) } \\
\text { Kitab Sadiram }\end{array}$ & Tidak dicantumkan nama penerjemah \\
\hline 12 & $\begin{array}{l}\text { Kitab Muluk al-Hindi fi'l- } \\
\text { Qitali wal Siyah (berisi kisah } \\
\text { raja-raja India di dalam } \\
\text { peperangannya dan } \\
\text { pengembaranya) }\end{array}$ & Tidak dicantumkan nama penerjemah \\
\hline 13 & $\begin{array}{l}\text { Kitab fi'l-Musiqi wa Ushhul al- } \\
\text { Hani (mengenai music dasar } \\
\text { beserta nada lagu) }\end{array}$ & Tidak dicantumkan nama penerjemah \\
\hline
\end{tabular}

Keterlibatan para penerjemah yang datang berbondong-bondong dari berbagai negara dengan latar belakang agama yang berbeda-beda pada masa kepemimpinan Harun Ar-Rasyid dan Al-Ma'mun, salah satu suntikan semangatnya adalah karena adanya upah yang diberikan sebagai balasan jasa atas usaha yang dilakukan yaitu dengan memberikan imbalan yang sangat seimbang, emas seberat buku atau karya yang telah diterjemahkan. Selain itu keuntungan juga didapat bagi Bait al-hikmah (akademi ilmu pengetahuan) di Bagdad, yaitu mendapatkan limpahan karya-karya asing maupun asli yang sudah diterjemahkan dan menjadi kumpulan keilmuan bagi peradaban ilmu pengetahun Islam.

Atas usaha yang dilakukan oleh ilmuan muslim, sehingga lahirlah para saintis, ulama, filosof dan sastrawan Islam yang terkenal. Pada bidang astronomi dikenal dengan nama AlFarizi astronom Islam pertama kali yang menyusun astrolabe (alat pengukur ketinggian benda langit). Ar-Razi dan Ibn Sina dikenal dalam bidang kedokteran, di mana Ar-Razi adalah tokoh pertama yang membedakan antara penyakit cacar dan measles (campak/cacar air), dengan karyanya menerbitkan sebuah buku mengenai kedokteran anak, selain kedokteran, Ibn Sina juga sebagai seorang filosof yang berhasil menemukan sistem peredaran darah pada manusia, diantara karyanya yaitu Al-Qanun Fi Al-Thibb yang merupakan ensiklopedia kedokteran paling besar dalam sejarahnya. Kemudian di bidang optika terdapat Abu Ali AlHasan Ibn Haythami dan pada bidang kimia terkenal nama Jabir Ibn Hayyan, sedangkan pada bidang matematika ada Muhammad Ibn Musa Al-Khawarizmi yang juga mahir dalam bidang astronomi dan telah menciptakan aljabar, serta Al-Mas'udi yang ahli dalam bidang ilmu geografi diantara karyanya adalah Muruj Al-Zahab wa Ma'adin Al-Jawahir. Untuk tokohtokoh yang terkenal dalam bidang filsafat antara lain ada Ibn Farabi, Ibn Sina dan Ibn Rusyd. ${ }^{35}$ Terdapat pula pendiri mazhab hukum Islam, diantaranya Abu Hanafi, Syafi'i dan Ahmad Ibn Hambal, Al-Ghazali yang dikenal sebagai filosof, teolog dan sufi besar dalam

${ }^{35}$ Badri Yatim, "Sejarah Peradaban Islam", h. 58 
Islam yang memiliki julukan Hujjah al-Islam, kemudian ada pula Abd Al-Qadir Al-Jilani pendiri dari tarekat Qadiriyah dan Ibn Muqaffa seorang sastrawan besar. ${ }^{36}$

Kemajuan sains yang diraih oleh para ilmuan muslim, pada dasarnya disebabkan oleh banyak faktor baik itu dari internal maupun eksternal. Dari aspek internal terdapat semangat normatif yang dimiliki saintis muslim karena terinspirasi oleh ajaran Al-Qur'an dan Al-Hadis mengenai konsep ilmu dan pengembangannya. Kemudian dari aspek eksternal adanya dukungan penuh yang diberikan oleh khalifah dalam pengembangan ilmu pengetahuan. Terkadang khalifah bertindak bukan sebagai fasilitator semata, tapi bisa langsung menjadi inisiator. Di sisi lain adanya sikap ilmiah yang terbuka, obyektif dan kritis dari para ilmuan muslim merupakan salah satu pendorong, terjadinya kemajuan dalam bidang sains. ${ }^{37}$

Eksistensi ilmu pengetahuan dan sains di masa Dinasti Abbasiyah tidak dapat dilepaskan dari peran aktif dan kesadaran dari para khalifah, khusunya Al-Mansur, khalifah Harun Ar-Rasyid dan khalifah Al-Makmun, yang sangat mencurahkan perhatian mereka pada pertumbuhan dan perkembangan ilmu pengetahuan serta filsafat di zaman mereka. ${ }^{38}$ Kemajuan dinasti Abbasiyah dalam bidang ilmu pengetahuan yang monumental ini tidak bisa dipisahkan dari adanya gerakan penerjemah buku-buku asing dan lembaga pendidikan yang didirikan oleh khalifah Harun Ar-Rasyid dan Al-Ma'mun.

Selain itu dari hasil penerjemahan yang dilakukan, kemudian membuat uraian-uraian beserta melakukan penyempurnaan untuk membuat karya-karya baru, namun tetap disesuaikan dengan latar belakang keilmuan dan agama Islam. Pada periode-periode selanjutnya mucul sejumlah nama-nama ilmuan dari kalangan agama Islam dan menjadi tokoh-tokoh terkenal dalam bidang disiplin ilmu pengetahun masing-masing yang ditekuni. Dengan adanya gerakan penerjemah ini, umat Islam juga seperti mendapatkan udara segar kembali dan pencerahan akan keilmuan-keilmuan baru yang mulai dikenalnya untuk kemudian dikembangkan.

\section{Penutup}

Gerakan penerjemah merupakan salah satu cara yang dilakukan khalifah Harun ArRasyid dan Al-Ma'mun sebagai wujud bentuk kecintaannya terhadap ilmu pengetahuan, yang kemudian mengembangkannya dalam bentuk real action dengan melakukan penerjemahan terhadap karya-karya kuno yang sudah mengalami kemajuan terlebih dahulu diantaranya yaitu Yunani, India dan Parsia.

Para penerjemah sangat antusias datang dari berbagai penjuru negara yang ingin ikut terlibat dalam usaha penerjemahan yang dilakukan oleh ke dua khalifah tersebut. Tentunya hal ini sudah direncanakan oleh Harun Ar-Rasyid dan Al-Ma'mun secara matang-matang untuk menarik para penerjemah yang menguasai ilmu bahasa dengan memberikan penghargaan berupan upah atau bayaran emas seberat buku atau karya yang telah diterjemahkan, hal inilah yang kemudian membuat para penerjemah datang dengan tidak memperdulikan latar belakang negara, agama, RAS dan khalifahpun memiliki keterbukaan bagi siapa saja yang ingin ikut terlibat dalam usaha penerjemah yang digalakkan, hingga pada akhirnya tidak sedikit para penerjemah yang masuk Islam.

Berkat gerakan penerjemah inilah ilmu pengetahuan Islam mengalami peradaban yang sangat besar, hingga sampai saat ini karya-karya dari para ilmuan muslim baik dalam bidang kedokteran, filsafat, astronomi dan bidang sains lainnya diabadikan dan tercatat dalam buku sejarah sumbangan Islam kepada ilmu dan peradaban modern. Bukan hanya menjadi sebuah

\footnotetext{
${ }^{36}$ Badri Yatim, "Sejarah Peradaban Islam", h. 278

${ }^{37}$ Muqowim, "Genealogi Intelektual Saintis Muslim, Sebuah Kajian Tentang Pola Pengembangan Sains Dalam Islam Pada Periode Abbasyiah”, h. 4-5

${ }^{38}$ Mochamad Muksin, "Islam Dan Perkembangan Sains Dan Teknologi, Studi Perkembangan Sains Dan Teknologi Dinasti Abbasyiah”, h. 18
} 
buku bacaan namun dalam praktik dan keilmuannya, karya-karya keilmuan tersebut diakui dan sudah nyata difungsikan serta diterapkan dalam kehidupan baik itu di Timur maupun di Barat, maka pantaslah jika gerakan penerjemah disebut sebagai masa kejayaan, dengan tidak melupakan tokoh-tokoh yang sudah ikut andil dalam proses penerjemahan buku-buku ilmu pengetahuan ke dalam bahasa Arab.

\section{Daftar Pustaka}

Alimni. "Peradaban Pendidikan; Gerakan Intelektual Masa Abbasiyah". Jurnal Al-Ta'lim, Vol. 13, No. 2, Juli 2014.

Amin, Ahmad. Dhuha al-Islam. Kairo : Lajnah Al-Ta'lif wa Al-Nasyr, tanpa tahun.

Asari, Hasan. Menyingkap Zaman Keemasan Islam. Bandung : Mizan, 1994.

Intan, Salmah. "Kontribusi dinasti Abbasiyah Bidang Ilmu Pengetahuan". Jurnal Rihlah Vol. 6 No. 2 tahun 2018.

Jallani, Imam Amrusi. "Kontribusi Ilmuan Muslim dalam Perkembangan Sains Modern". Jurnal Theologia, Vol 29 No 1, 2018.

Muksin, Mochamad. "Islam dan Perkembangan Sains dan Teknologi, Studi Perkembangan Sains dan Teknologi Dinasti Abbasyiah". Jurnal Vol 2, Nomor 4, 2016.

Muqowim. Genealogi Intelektual Saintis Muslim, Sebuah Kajian Tentang Pola Pengembangan Sains dalam Islam Pada Periode Abbasyiah. Yogyakarta : Kementerian Agama, 2012.

Nurhakim, Imam. “Kebijakan Khalifah Al-Ma'mun Tentang Pendidikan Islam”. Jurnal AnNidzam Volume 04, No. 01, Januari-Juni 2017.

Poeradisastra. Sumbangan Islam kepada Ilmu dan Peradaban Modern. Jakarta : Komunitas Bambu, 2008.

Sou’yb, Joesoef . Sejarah Daulat Abbasiyah. Jakarta : Bulan Bintang, 1977.

Syalabi, Ahmad. Sejarah dan Kebudayaan Islam-III Terjemahan Ast. Muhammad Labib Ahmad. Jakarta : Pustaka Al Husna 1993.

Yanto. "Sejarah Perpustakaan Bait Al-Hikmah Pada Masa Keemasan Dinasti Abbasiyah". Jurnal Tamaddun Vol. Xv, No. 1/Januari-Juni 2015.

Yatim, Badri. Sejarah Peradaban Islam. Jakarta : PT RajaGrafindo Persada, 2013. 